\title{
Penentuan Prioritas Perbaikan Jalan di Desa Gawan Menggunakan Algoritma Analytical Hierarchy Process
}

\author{
Muhammad Rifal Alfarizy ${ }^{1}$, Mochammad Hazmi Cokro Mandiri ${ }^{2}$, Yufis Azhar $^{3}$ \\ 1,2,3 Universitas Muhammadiyah Malang \\ Jl. Bendungan Sutami No.188, Sumbersari, Kec. Lowokwaru, Kota Malang, Indonesia \\ e-mail: '1mrifala29@gmail.com, 2hazmicokro@gmail.com, 33yufis@umm.ac.id
}

\begin{abstract}
\begin{tabular}{llll}
\hline Informasi Artikel & Diterima: 06-06-2020 & Direvisi: 28-07-2020 & Disetujui: 10-02-2021
\end{tabular}
Abstrak

Seiring berjalannya waktu, jalan dapat mengalami penurunan kualitas hingga kerusakan. Kerusakan jalan tentunya sangat mengganggu aktivitas masyarakat dan akan menjadi lebih buruk ketika banyak jalan yang rusak secara bersamaan dalam waktu dekat. Maka dari itu, diperlukan tindakan perawatan dan perbaikan jalan dengan cepat dan tepat. Penelitian ini dilakukan di Desa Gawan dan bertujuan untuk menentukan prioritas perbaikan jalan menggunakan metode AHP. Kriteria yang digunakan dalam metode AHP ini adalah kondisi jalan, perkerasan jalan, status jalan, fungsi jalan, dan kelas jalan. Berdasarkan penelitian ini, kriteria yang memiliki nilai tertinggi adalah kondisi jalan dengan nilai 0.505. Nilai akhir pada penelitian ini memiliki kesamaan antar beberapa ruas jalan, maka dari itu dilakukan evaluasi kembali dengan membandingan panjang dan lebar jalan masing-masing ruas dengan memprioritaskan jalan dengan luas jalan yang lebih besar daripada luas jalan yang kecil sesuai dengan hasil pembobotan oleh responden. Hasil akhir penelitian berupa ruas jalan dengan kode 540900081082 menjadi prioritas pertama untuk perbaikan dengan nilai akhir 0.312172641 dan kondisi jalan rusak.
\end{abstract}

Kata Kunci: Prioritas, Perbaikan Jalan, AHP

\begin{abstract}
Over time, the road can experience quality degradation to damage. Road damage certainly disrupts community activities and will get worse when many roads are damaged simultaneously in the near future. Therefore, road maintenance and repairs are needed quickly and accurately. This research was conducted in Gawan Village and aims to determine the priority of road improvement using the AHP method. The criteria used in this AHP method are road conditions, road pavement, road status, road functions, and road class. Based on this study, the criterion that has the highest value is road conditions with a value of 0.505. The final value in this study has similarities between several road sections, therefore re-evaluation is done by comparing the length and width of the roads of each section by prioritizing the road with a larger road area than the small road area in accordance with the results of the weighting by respondents. The final results of the study in the form of a road section with code 540900081082 became the first priority for improvement with a final value of 0.312172641 and damaged road conditions.
\end{abstract}

Keywords: Priority, Road Maintenance, AHP

\section{Pendahuluan}

Pertumbuhan dan perkembangan masyarakat suatu daerah tentu tidak lepas dari sarana dan prasarana yang tersedia. Sarana dan prasarana yang baik akan menunjang kegiatan ekonomi, sosial, dan budaya dari daerah tersebut. Salah satu prasarana yang berpengaruh bagi masyarakat adalah jalan. Seiring berjalannya waktu, jalan dapat mengalami kerusakan yang disebabkan oleh tingginya intensitas kendaraan yang melewatinya. Hal tersebut dapat mengganggu aktivitas dan membahayakan masyarakat yang menggunakannya. Tindakan perbaikan secara cepat memang dibutuhkan untuk memperbaiki jalan. Namun, banyaknya kerusakan jalan yang terjadi secara bersamaan membuat tindakan cepat terhadap perbaikan jalan menjadi kurang tepat dan efektif. Hal ini dapat diselesaikan dengan membuat pendukung keputusan yang menghasilkan keluaran berupa urutan prioritas jalan yang sebaiknya diperbaiki terlebih dahulu berdasarkan pertimbangan terhadap berbagai 
kondisi jalan sehingga meningkatkan efektivitas dalam perbaikan jalan secara keseluruhan.

Penelitian terkait pendukung keputusan telah banyak dilakukan dengan bermacammacam metode yang digunakan seperti SAW, Sistem Pakar, Regresi Linier, B/C Ratio, NPV, IRC dan AHP. Dalam kasus penentuan prioritas, metode SAW dan AHP lebih sering digunakan untuk menyelesaikan masalahnya. Pada penelitian ini, kami akan menggunakan metode Analytical Hierarchy Process (AHP).

Analytical Hierarchy Process (AHP) bukanlah hal baru dalam pendukung keputusan, tetapi topik ini masih layak untuk diteliti lebih lanjut dengan studi kasus yang berbeda. Penelitian terkait Analytical Hierarchy Process (AHP) sebelumnya telah dilakukan oleh (Setiawan, 2019), dengan metode AHP untuk penentuan skala prioritas penanganan ruas jalan provinsi di Kabupaten Purwakarta. Pada penelitian yang dilakukan (Setiawan, 2019), dilakukan pengumpulan data dengan melakukan kuisioner pada koresponden expert sehingga kriteria yang digunakan adalah Kondisi Jalan, Volume Lalu Lintas, Tata Guna Lahan, Kepadatan Penduduk, Ekonomi, dan Kebijakan Eksekutif. Hasil penelitian tersebut adalah model persamaan matematis untuk menentukan urutan prioritas penanganan yang tepat pada jaringan ruas jalan tersebut.

Menurut (Saaty, 1993) metode AHP adalah metode pengambilan keputusan yang bersifat luas dan lengkap meliputi berbagai aspek atau kriteria yang luas, serta memperhitungkan hal-hal yang bersifat kuantitatif dan kualitatif. Kriteria yang ditentukan dalam penentuan prioritas perbaikan jalan dengan Metode AHP ini sangatlah beragam. Hal tersebut dapat mempengaruhi kualitas dan ketepatan dari prioritas yang dihasilkan.

Pada penelitian ini, kriteria yang digunakan antara lain : (1) Kondisi Jalan; (2) Fungsi Jalan; (3) Status Jalan; (4) Kelas Jalan; dan (5) Perkerasan Jalan. Pembobotan akan dilakukan pada 5 kriteria inti tersebut dengan sub-kriteria didalamnya dan apabila terdapat nilai yang sama dari pembobotan, maka akan dilakukan perbandingan dengan alternatif kriteria (1) Panjang Jalan dan (2) Lebar Jalan.

\section{Metode Penelitian}

Penelitihan ini memiliki beberapa tahapan yang dimulai dari pengumpulan data hingga implementasi AHP. Tahapan untuk penelitian ini dapat dilihat pada Gambar 1.

1. Data

Data yang digunakan dalam penelitian didapatkan dengan 2 cara, cara yang pertama adalah pendataan secara langsung di lokasi Desa Gawan, Kecamatan Tanon, Kabupaten Sragen. Data ini dikumpulkan pada akhir tahun 2019 hingga awal tahun 2020. Data tersebut memiliki 15 atribut dengan 216 banyak data. Macam-macam atribut dari data tersebut adalah:

a) Kode Jalan

Atribut ini berisi kode untuk masing-masing ruas jalan yang ada di desa gawan, dengan kata lain, atribut ini merupakan penamaan atau label dari masing-masing jalan.

b) Lokasi Jalan (Koordinat)

Lokasi jalan berisi 4 atribut yang berisi koordinat dari masing-masing ruas jalan. Atribut tersebut adalah $x$ awal, $y$ awal, $x$ akhir dan y akhir.

c) Panjang Jalan

Atribut ini berisi panjang jalan dari masingmasing ruas jalan. Satuan dari data panjang jalan adalah meter.

d) Lebar Jalan

Atribut ini berisi lebar jalan dari masingmasing ruas jalan. Satuan dari data lebar jalan adalah meter.

e) Bahu Kanan

Atribut ini berisi lebar bahu kanan jalan. Satuan dari data bahu kanan adalah meter.

f) Bahu Kiri

Atribut ini berisi lebar bahu kiri jalan. Satuan dari data bahu kiri adalah meter.

g) Tahun Perbaikan Jalan

Atribut ini berisi data tentang tahun terakhir jalan diperbaiki, jika jalan belum pernah diperbaiki, maka data akan berisi nilai 0 .

h) Status Jalan

Data ini merupakan hasil pengelompokan dari status jalan. Berdasarkan studi kasus saat ini, status jalan hanya terbagi menjadi Jalan Desa dan Jalan Provinsi saja. Namun, status jalan seharusnya dibedakan menjadi 5 kelompok seperti : (1) Jalan Nasional; (2) Jalan Provinsi; (3) Jalan Kabupaten; (4) Jalan Kota; dan (5) Jalan Desa. 


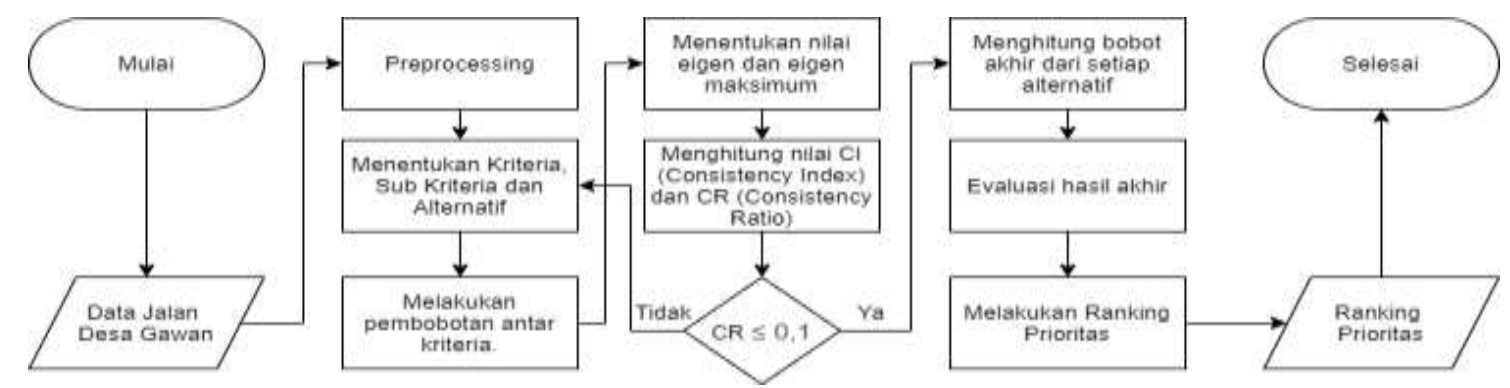

Gambar 1. Diagram Alur Penelitian

i) Fungsi Jalan

Data dalam atribut ini adalah hasil pengelompokan dari fungsi jalan. Namun, pada studi kasus saat ini tidak ditemukan jalan yang berfungsi menjadi jalan arteri. Berdasarkan fungsinya, atribut ini dikelompokkan menjadi 3 kelompok antara lain : (1) Jalan Kolektor; (2) Jalan Lokal; dan (3) Jalan Lingkungan.

j) Kelas Jalan

Data dalam atribut ini adalah hasil dari pengelompokan kelas jalan. Pada studi kasus saat ini, hanya terdapat 2 kelas jalan, jalan kecil dan jalan sedang.

k) Perkerasan Jalan

Atribut ini berisi data perkerasan atau material penyusun masing-masing jalan. Pada studi kasus saat ini, terdapat 5 kelompok perkerasan jalan, antara lain : (1) Tanah; (2) Paving; (3) Rabat Beton; (4) Beton; dan (5) Aspal.

I) Kondisi Jalan

Atribut ini berisi data kondisi jalan yang telah dikelompokkan menjadi 9 bagian, yaitu: (1) Baik; (2) Bergelombang; (3) Berlubang; (4) Retak; (5) Retak dan Bergelombang; (6) Retak dan Berlubang; dan (7) Retak, Bergelombang dan Berlubang

Cara kedua pengumpulan data tersebut adalah dengan melakukan survey kepada responden yang berkompeten dalam bidangnya untuk menentukan kriteria dan pembobotan kriteria. Responden yang digunakan dalam penelitian ini adalah Mahasiswa semester akhir jurusan Perencanaan Wilayah dan Kota.

\section{Preprocessing}

Data yang sudah terkumpul melalui survey merupakan data kotor dan diperlukan preprocessing data. Pada tahap ini dilakukan pengecekan data masing-masing kriteria, kemudian dilakukan:

1. Pengisian data yang kosong dengan melakukan konfirmasi tentang kekosongan data kepada pemilik data, apabila memang data tersebut kosong, maka akan diisi dengan kata 'tidak ada'.
2. Pengecekan kata / huruf yang salah pada setiap data di kriteria.

3. Menghapus baris data yang memiliki banyak data kosong.

4. Menyetarakan isi data dengan menghapus data yang didalamnya ditulis satuan dari data tersebut.

\section{Analytical Hierarchy Process}

Analytical Hierarchy Process (AHP) merupakan metode pengambilan keputusan dengan melakukan perbandingan berpasangan antara kriteria dan sub kriteria (Saaty,1993). Pengambilan keputusan pada AHP umunya dibagi menjadi kriteria, dan sub kriteria. AHP memiliki kelebihan dibandingkan dengan metode yang lain karena struktur dari AHP berbentuk hierarki, yang berisi dari kriteria, hingga kepada sub- sub kriteria. Langkahlangkah pengambilan keputusan dengan metode AHP adalah sebagai berikut:

a) Mendefinisikan masalah, membuat hierarki dan pemilihan kriteria.

Pada tahap ini, masalah yang akan diselesaikan adalah penentuan prioritas perbaikan jalan. Kriteria yang akan digunakan adalah (1) Kondisi Jalan, (2) Fungsi Jalan, (3) Status Jalan, (4) Kelas Jalan, dan (5) Perkerasan Jalan. Struktur Hierarki Model AHP penelitian ini dapat dilihat pada gambar 2 .

b) Perbandingan Kriteria.

Perbandingan dilakukan dengan cara berpasangan setiap kriteria maupun subkriteria, nilai dari perbandingan ditentukan berdasarkan skala pembobotan seperti pada tabel 1. 


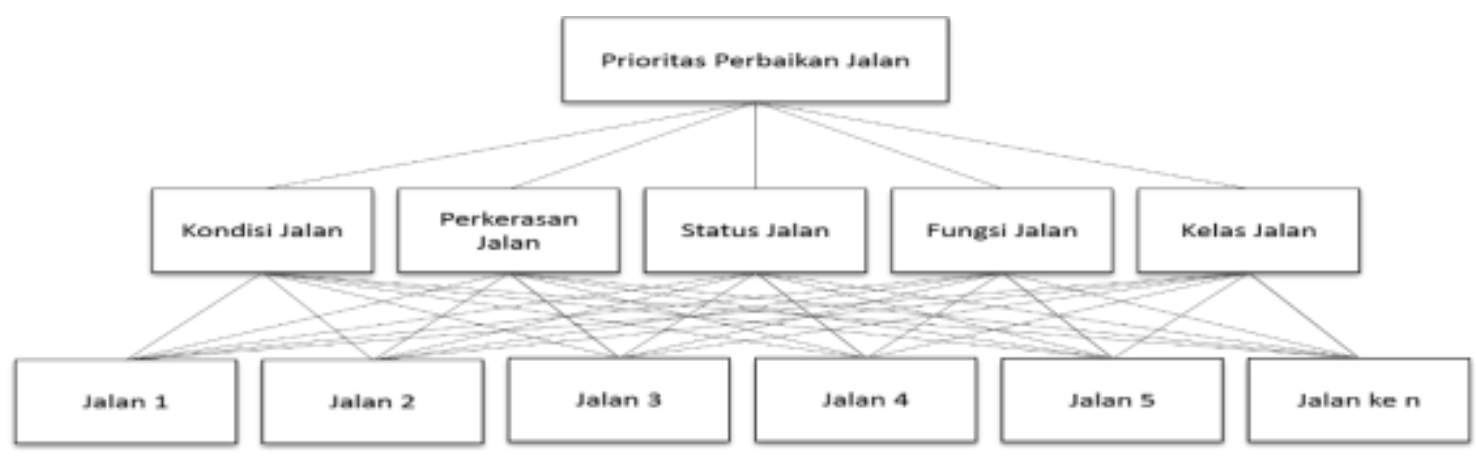

Gambar 2. Struktur Hierarki Model AHP

c) Perbandingan Kriteria.

Perbandingan dilakukan dengan cara berpasangan setiap kriteria maupun subkriteria, nilai dari perbandingan ditentukan berdasarkan skala pembobotan seperti pada tabel 1.

Tabel 1. Skala Pembobotan

\begin{tabular}{cc}
\hline Skala & Definisi \\
\hline 1 & Sama penting \\
3 & Sedikit lebih penting \\
5 & Cukup penting \\
7 & Sangat penting \\
9 & Multak lebih penting \\
Nilai tengah antara \\
dua nilai keputusan \\
$2,4,6,8$ & yang berdekatan \\
\hline \multicolumn{2}{c}{}
\end{tabular}

Hasil dari perbandingan akan berupa matriks bernilai positif dan berbalikan.

d) Mencari nilai eigen \& eigen maksimal.

Proses ini dilakukan dengan mencari nilai eigen tertinggi untuk menentukan bobot tertinggi sebagai bobot relatif dari vektor eigen $(\mathrm{w})$ sesuai nilai eigen tertinggi

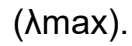

$$
A w=\lambda_{\text {max }} W
$$

Hal tersebut dilakukan dengan cara sebagai berikut :

1. Menghitung jumlah dari setiap kolom matriks.

2. Membuat matriks eigen dengan nilai matriks perbandingan dibagi jumlah dari kolom indeks yang sama.

3. Melakukan rata-rata baris matriks eigen untuk mendapatkan nilai eigen.

e) Mengukur nilai $\mathrm{Cl}$ dan $\mathrm{CR}$.

Nilai konsistensi diperoleh dengan cara membagi hasil $\lambda_{\max }{ }-\mathrm{n}$ ( $\mathrm{n}$ merupakan total elemen yang digunakan dalam matriks perbandingan) dengan nilai $n-1$.

$$
C I=\frac{\left(\lambda_{\max }-\mathrm{n}\right)}{n-1}
$$

Kemudian dilakukan evaluasi untuk mengevaluasi hasil apakah konsisten atau tidak dengan menghitung nilai CR (Consistency Ratio).

$$
C R=\frac{\mathrm{CI}}{R I} \leq 0,1
$$

CR dapat diperoleh dengan membagi $\mathrm{Cl}$ (Consistency Index) dengan RI (Random Index). Nilai CR harus $\leq 0,1$ jika tidak, maka dilakukan pembobotan ulang kriteria. Nilai $\mathrm{RI}$ didapatkan berdasarkan tabel berikut :

Tabel 2. Random Index

\begin{tabular}{cccccc}
\hline $\mathrm{n}$ & 1 & 2 & 3 & 4 & 5 \\
\hline $\mathrm{RI}$ & 0 & 0 & 0.58 & 0.9 & 1.12 \\
$\mathrm{n}$ & 6 & 7 & 8 & 9 & 10 \\
$\mathrm{RI}$ & 1.24 & 1.32 & 1.41 & 1.45 & 1.49 \\
\hline
\end{tabular}

f) Menghitung nilai akhir dan menentukan prioritas.

Penentuan urutan prioritas perbaikan jalan dilakukan dengan menggunakan perhitungan model matematis menurut (Brodjonegoro, 1991), yaitu:

$$
\begin{aligned}
Y= & A\left(a_{1} \times X_{1}+\ldots+a_{6} \times X_{6}+\right. \\
& B\left(b_{1} \times X_{7}+\ldots+b_{7} \times X_{13}\right)+ \\
& C\left(c_{1} \times X_{14}+\ldots+c_{2} \times X_{15}\right)
\end{aligned}
$$

Keterangan:

$\mathrm{Y}=$ Prioritas Perbaikan Ruas Jalan (Nilai akhir pembobotan)

A $s / d \quad C=$ Bobot kriteria (data analisa responden)

$\mathrm{a} 1, \mathrm{a} 2, \mathrm{a} 3 \ldots \mathrm{c} 2$ = Bobot subkriteria (data analisa responden)

$\mathrm{X} 1, \mathrm{X} 2, \ldots, \mathrm{X} 15=$ Bobot subkriteria (data survey) 


\section{Evaluasi Hasil}

Pada tahap ini, dilakukan evaluasi pada hasil nilai akhir untuk mengatasi permasalahan nilai yang sama. Ruas jalan yang memiliki nilai sama akan diurutkan berdasarkan luas jalan terbesar akan menjadi prioritas. Hal tersebut diambil berdasarkan bobot responden yang lebih memilih jalan sedang daripada jalan kecil.

\section{Hasil dan Pembahasan}

1. Pembobotan Kriteria dan Sub Kriteria.
Pembobotan kriteria dan sub kriteria ini dilakukan dengan cara wawancara kepada Mahasiswa semester akhir jurusan Perencaan Wilayah dan Kota Universitas Diponegoro. Pembobotan ini telah dilakukan evaluasi untuk menjaga nilai konsistensi dalam pembobotannya. Hasil dari skala pembobotan kriteria dapat dilihat pada tabel 3 dan hasil dari skala pembobotan salah satu sub kriteria yaitu fungsi jalan dapat dilihat pada tabel 4 .

Tabel 3. Skala Pembobotan Kriteria

\begin{tabular}{|c|c|c|c|c|c|c|c|c|c|c|c|c|c|c|c|c|c|c|}
\hline \multirow{2}{*}{ Kriteria A } & \multicolumn{17}{|c|}{ Skala } & \multirow{2}{*}{ Kriteria B } \\
\hline & 9 & 8 & 7 & 6 & 5 & 4 & 3 & 2 & 1 & 2 & 3 & 4 & 5 & 6 & 7 & 8 & 9 & \\
\hline $\begin{array}{c}\text { Kondisi } \\
\text { Jalan }\end{array}$ & & & & & & & $\checkmark$ & & & & & & & & & & & Perkerasan Jalan \\
\hline $\begin{array}{l}\text { Kondisi } \\
\text { Jalan }\end{array}$ & $\checkmark$ & & & & & & & & & & & & & & & & & Status Jalan \\
\hline $\begin{array}{l}\text { Kondisi } \\
\text { Jalan }\end{array}$ & & & & & $\checkmark$ & & & & & & & & & & & & & Fungsi Jalan \\
\hline $\begin{array}{l}\text { Kondisi } \\
\text { Jalan }\end{array}$ & & & & $\checkmark$ & & & & & & & & & & & & & & Kelas Jalan \\
\hline $\begin{array}{l}\text { Perkerasan } \\
\text { Jalan }\end{array}$ & & & & $\checkmark$ & & & & & & & & & & & & & & Status Jalan \\
\hline $\begin{array}{c}\text { Perkerasan } \\
\text { Jalan }\end{array}$ & & & & & & & & $\checkmark$ & & & & & & & & & & Fungsi Jalan \\
\hline $\begin{array}{l}\text { Perkerasan } \\
\text { Jalan }\end{array}$ & & & & & & & $\checkmark$ & & & & & & & & & & & Kelas Jalan \\
\hline Status Jalan & & & & & & & & & & & & $\checkmark$ & & & & & & Fungsi Jalan \\
\hline Status Jalan & & & & & & & & & & & $\checkmark$ & & & & & & & Kelas Jalan \\
\hline Fungsi Jalan & & & & & $\checkmark$ & & & & & & & & & & & & & Kelas Jalan \\
\hline
\end{tabular}

Tabel 4. Skala Pembobotan Sub Kriteria Perkerasaan Jalan

\begin{tabular}{|c|c|c|c|c|c|c|c|c|c|c|c|c|c|c|c|c|c|c|}
\hline \multirow{2}{*}{ Kriteria A } & \multicolumn{17}{|c|}{ Skala } & \multirow{2}{*}{ Kriteria B } \\
\hline & 9 & 8 & 7 & 6 & 5 & 4 & 3 & 2 & 1 & 2 & 3 & 4 & 5 & 6 & 7 & 8 & 9 & \\
\hline Aspal & & & & & & & & $\checkmark$ & & & & & & & & & & Beton \\
\hline Aspal & & & & & & & & & & & $\checkmark$ & & & & & & & Paving \\
\hline Aspal & & & & & & & & & & $\checkmark$ & & & & & & & & Rabat Beton \\
\hline Aspal & & & & & & & & & & & & & & $\checkmark$ & & & & Tanah \\
\hline Beton & & & & & & & & & & & & $\checkmark$ & & & & & & Paving \\
\hline Beton & & & & & & & & & & & $\checkmark$ & & & & & & & Rabat Beton \\
\hline Beton & & & & & & & & & & & & & & & $\checkmark$ & & & Tanah \\
\hline Paving & & & & & & & & $\checkmark$ & & & & & & & & & & Rabat Beton \\
\hline Paving & & & & & & & & & & & & $\checkmark$ & & & & & & Tanah \\
\hline $\begin{array}{l}\text { Rabat } \\
\text { Beton }\end{array}$ & & & & & & & & & & & & & $\checkmark$ & & & & & Tanah \\
\hline
\end{tabular}


2. Perhitungan Nilai Eigen dan Eigen Maksimal. Langkah pertama dari tahap ini adalah menjadikan seluruh hasil pembobotan dari responden menjadi Matriks sebuah matriks yang berisi data sesuai hasil pembobotan dan nilai kebalikan dari data tersebut yang didapat dari membagi angka 1 dengan nilai hasil masing-masing pembobotan yang bersangkutan. Tabel matriks kriteria dan salah satu kriteria dapat dilihat pada tabel 5 dan tabel 6.

Tabel 5. Matriks Kriteria

\begin{tabular}{cccccc}
\hline Kriteria & $\begin{array}{c}\text { Kondisi } \\
\text { Jalan }\end{array}$ & $\begin{array}{c}\text { Perkerasan } \\
\text { Jalan }\end{array}$ & $\begin{array}{c}\text { Status } \\
\text { Jalan }\end{array}$ & $\begin{array}{c}\text { Fungsi } \\
\text { Jalan }\end{array}$ & Kelas Jalan \\
\hline Kondisi Jalan & 1 & 3 & 9 & 5 & 6 \\
Perkerasan Jalan & 0.333 & 1 & 6 & 2 & 3 \\
Status Jalan & 0.111 & 0.167 & 1 & 0.25 & 0.333 \\
Fungsi Jalan & 0.2 & 0.5 & 4 & 1 & 5 \\
Kelas Jalan & 0.167 & 0.333 & 3 & 0.2 & 1 \\
Jumlah & 1.811 & 5 & 23 & 8.45 & 15.333 \\
\hline
\end{tabular}

Tabel 6. Matriks Sub Kriteria Perkerasaan Jalan

\begin{tabular}{cccc}
\hline Sub Kriteria & Kolektor & Lingkungan & Lokal \\
\hline Kolektor & 1 & 9 & 8 \\
Lingkungan & 0.111 & 1 & 0.5 \\
Lokal & 0.125 & 2 & 1 \\
Jumlah & 1.236 & 12 & 9.5 \\
\hline
\end{tabular}

Tabel 7. Matriks Eigen Kriteria

\begin{tabular}{ccccccc}
\hline Kriteria & \multicolumn{7}{c}{ Eigen } & & & Rata - Rata \\
\hline $\begin{array}{c}\text { Kondisi } \\
\text { Jalan }\end{array}$ & 0.552 & 0.6 & 0.391 & 0.592 & 0.391 & 0.505 \\
$\begin{array}{c}\text { Perkerasan } \\
\text { Jalan }\end{array}$ & 0.184 & 0.2 & 0.261 & 0.237 & 0.196 & 0.215 \\
$\begin{array}{c}\text { Status Jalan } \\
\text { Fungsi }\end{array}$ & 0.061 & 0.0333 & 0.043 & 0.030 & 0.022 & 0.038 \\
$\begin{array}{c}\text { Jalan } \\
\text { Kelas Jalan }\end{array}$ & 0.110 & 0.1 & 0.174 & 0.118 & 0.326 & 0.166 \\
\hline Jumlah & 0.092 & 0.067 & 0.130 & 0.024 & 0.065 & 0.076 \\
\hline
\end{tabular}

Tabel 8. Matriks Eigen Sub Kriteria Perkerasaan Jalan

\begin{tabular}{|c|c|c|c|c|c|c|}
\hline Sub Kriteria & & & Eigen & & & Rata - Rata \\
\hline Aspal & 0.08 & 0.118 & 0.055 & 0.057 & 0.095 & 0.081 \\
\hline Beton & 0.04 & 0.059 & 0.041 & 0.038 & 0.081 & 0.052 \\
\hline Paving & 0.24 & 0.235 & 0.164 & 0.226 & 0.142 & 0.202 \\
\hline Rabat Beton & 0.16 & 0.176 & 0.082 & 0.113 & 0.114 & 0.129 \\
\hline Tanah & 0.48 & 0.412 & 0.658 & 0.566 & 0.568 & 0.537 \\
\hline Jumlah & & & & & & 1 \\
\hline
\end{tabular}

Setelah mengubah data pembobotan menjadi matriks, langkah kedua adalah membuat matriks eigen dari kriteria dan subkriteria. Nilai matriks eigen didapat dari nilai dalam matriks kriteria / subkriteria dengan indeks yang sama, dibagi jumlah dari kolom indeks di matriks tersebut. Nilai eigen didapatkan dengan menghitung rata-rata setiap 
baris matriks eigen, hasil dari matriks eigen kriteria dan salah satu subkriteria dapat dilihat pada tabel ke 7 dan tabel ke 8 yang ada diatas.

Sedangkan nilai eigen maksimal $\left(\lambda_{\max } w\right)$ didapatkan dengan membagi jumlah dari setiap kolom matriks kriteria dan subkriteria dengan nilai eigen masing-masing. Nilai eigen maksimal dari setiap matriks dapat dilihat pada tabel 9.

Tabel 9. Eigen Maksimal

\begin{tabular}{cc}
\hline & $\lambda_{\max } W$ \\
\hline Kriteria & 5.423901 \\
Kondisi Jalan & 9.829457 \\
Perkerasan Jalan & 5.200957 \\
Status Jalan & 2 \\
Fungsi Jalan & 3.074086 \\
Kelas Jalan & 2 \\
\hline
\end{tabular}

3. Perhitungan Nilai $\mathrm{Cl}$ dan $\mathrm{CR}$.

Berdasarkan perhitungan, nilai $\mathrm{CR}$ dalam setiap matriks dikatakan konsisten karena memperoleh nilai $\mathrm{CR} \leq 0,1$. Penelitian ini sempat dilakukan evaluasi pembobotan kriteria dan subkriteria karena terdapat beberapa dari kriteria dan subkriteria yang mendapatkan nilai $\mathrm{CR} \leq 0,1$. Nilai $\mathrm{Cl}$ dan $\mathrm{CR}$ dari setiap matriks dapat dilihat pada tabel 10 .

Tabel 10. Nilai Cl dan CR

\begin{tabular}{ccc}
\hline & $\mathrm{Cl}$ & $\mathrm{CR}$ \\
\hline Kriteria & 0.105975 & 0.094621 \\
Kondisi Jalan & 0.103682 & 0.071505 \\
Perkerasan & 0.050239 & 5.200957 \\
Jalan & $\infty$ & $\infty$ \\
Status Jalan & 0 & 0.063867 \\
Fungsi Jalan & 0.037043 & $\infty$ \\
Kelas Jalan & 0 & $\infty$ \\
\hline
\end{tabular}

4. Perhitungan Nilai Akhir Alternatif.

Berikut adalah hasil perhitungan akhir setiap alternatif yang disajikan dalam bentuk tabel dengan 10 Alternatif (Ruas Jalan) dengan nilai tertinggi untuk menjadi prioritas perbaikan jalan/ Hasil dari perhitungan akhir setiap alternatif dapat dilihat pada tabel 11 .

Tabel 11. Peringkat Prioritas 10 Ruas Jalan dengan Nilai Tertinggi

\begin{tabular}{cccccccc}
\hline \multirow{2}{*}{ Rank } & \multirow{2}{*}{ Kode Jalan } & $\begin{array}{c}\text { Status } \\
\text { Jalan }\end{array}$ & $\begin{array}{c}\text { Fungsi } \\
\text { Jalan }\end{array}$ & $\begin{array}{c}\text { Kelas } \\
\text { Jalan }\end{array}$ & $\begin{array}{c}\text { Perkerasan } \\
\text { Jalan }\end{array}$ & $\begin{array}{c}\text { Kondisi } \\
\text { Jalan }\end{array}$ & Nilai Akhir \\
\hline 1 & 540900081082 & 0.0037 & 0.0124 & 0.0075 & 0.1156 & 0.1727 & 0.3121726 \\
2 & 220910090091 & 0.0341 & 0.1326 & 0.068 & 0.0173 & 0.022 & 0.2743045 \\
3 & 220900088089 & 0.0341 & 0.1326 & 0.068 & 0.0111 & 0.009 & 0.2549912 \\
4 & 220900088092 & 0.0341 & 0.1326 & 0.068 & 0.0111 & 0.009 & 0.2549912 \\
5 & 220900089093 & 0.0341 & 0.1326 & 0.068 & 0.0111 & 0.009 & 0.2549912 \\
6 & 220911089090 & 0.0341 & 0.1326 & 0.068 & 0.0111 & 0.009 & 0.2549912 \\
7 & 220911089093 & 0.0341 & 0.1326 & 0.068 & 0.0111 & 0.009 & 0.2549912 \\
8 & 220911093094 & 0.0341 & 0.1326 & 0.068 & 0.0111 & 0.009 & 0.2549912 \\
9 & 220911094095 & 0.0341 & 0.1326 & 0.068 & 0.0111 & 0.009 & 0.2549912 \\
10 & 220911095096 & 0.0341 & 0.1326 & 0.068 & 0.0111 & 0.009 & 0.2549912 \\
\hline
\end{tabular}

5. Evaluasi Hasil

Berdasarkan hasil perhitungan nilai akhir terhadap 216 ruas jalan, terdapat beberapa ruas jalan yang memiliki nilai akhir yang sama. Seperti pada tabel 11, ruas jalan ke 3 hingga 10 memiliki nilai akhir yang sama. Maka pada tahap ini akan dilakukan perhitungan luas dan pemeringkatan kembali terhadap ruas jalan yang memiliki nilai akhir yang sama. Hasil evaluasi dapat dilihat di tabel 12.

Tabel 12. Pengecekan dan Perhitungan Luas Jalan

\begin{tabular}{cccc}
\hline Rank & Nilai Akhir & Cek & Luas \\
\hline 1 & 0.312172641 & 0 & 0 \\
\hline
\end{tabular}

\begin{tabular}{cccc}
\hline 2 & 0.27430456 & 0 & 0 \\
3 & 0.254991205 & 1 & 383.270951 \\
4 & 0.254991205 & 1 & 1195.93684 \\
5 & 0.254991205 & 1 & 86.103857 \\
6 & 0.254991205 & 1 & 447.914593 \\
7 & 0.254991205 & 1 & 804.019412 \\
8 & 0.254991205 & 1 & 568.83988 \\
9 & 0.254991205 & 1 & 220.673586 \\
10 & 0.254991205 & 1 & 779.715048 \\
\hline
\end{tabular}

Kolom Cek berisi nilai 1 atau 0, Angka 1 menunjukan bahwa data tersebut memiliki kesamaan dengan data lain yang berada dibawah atau diatas peringkat data tersebut. Kemudian berdasarkan kolom Cek, ruas yang 
memiliki nilai 1 akan dihitung luas jalannya dan diurutkan kembali berdasarkan luas jalan terbesar. Hasil Akhir perhitungan ruas jalan dapat dilihat di tabel 13.

Tabel 13. Hasil Akhir Prioritas Ruas Jalan untuk Perbaikan

\begin{tabular}{ccc}
\hline Rank & Kode Jalan & Nilai Akhir \\
\hline 1 & 540900081082 & 0.312172641 \\
2 & 220910090091 & 0.27430456 \\
3 & 220900088092 & 0.254991205 \\
4 & 220911089093 & 0.254991205 \\
5 & 220911095096 & 0.254991205 \\
6 & 220911093094 & 0.254991205 \\
7 & 220911089090 & 0.254991205 \\
8 & 220900088089 & 0.254991205 \\
9 & 220911094095 & 0.254991205 \\
10 & 220900089093 & 0.254991205 \\
\hline
\end{tabular}

Hasil dari tahap evaluasi menyebabkan ruas jalan peringkat 3 sebelum evaluasi menjadi peringkat 9 , dan peringkat 4 menjadi peringkat 3 .

\section{Kesimpulan}

Berdasarkan penelitian yang dilakukan, maka dapat diambil beberapa kesimpulan, yaitu:

1. Hasil perhitungan nilai eigen untuk kriteria menunjukan bahwa Kondisi Jalan menjadi yang paling berpengaruh dalam penentuan prioritas dengan nilai eigen 0.505 . Sedangkan untuk subkriteria, Rusak mewakili Kondisi Jalan dengan nilai 0.342 , Tanah mewakili Perkerasan Jalan dengan nilai 0.537 , Kolektor mewakili Fungsi Jalan dengan nilai 0.537 , Jalan Sedang mewakili Kelas Jalan dengan nilai 0,9 dan Jalan Provinsi mewakili Status Jalan dengan nilai 0,9 .

2. Data pembobotan yang dilakukan responden adalah data konsisten. Hal tersebut terbukti berdasarkan hasil perhitungan $\mathrm{CR}$ dari kriteria dan subkriteria bernilai $\mathrm{CR}<0,01$.

3. Ruas jalan dengan kode 540900081082 menempati urutan pertama dalam prioritas perbaikan jalan, disusul dengan ruas jalan dengan kode 220910090091. Hal tersebut merupakan pemeringkatan yang tepat, karena kondisi dan status jalan tersebut adalah jalan desa dengan kondisi rusak dan jalan provinsi dengan kondisi berlubang.

4. Permasalahan ruas jalan yang memiliki nilai akhir yang sama dapat diselesaikan dengan perbandingan luas jalan dan jalan dengan luas terbesar menjadi prioritas, hal tersebut terbukti dengan ruas jalan yang sebelumnya berada di peringkat 3 menjadi peringkat 9 dan ruas jalan yang berada di peringkat 4 menjadi peringkat 3 .

Penelitian yang dilakukan ini memiliki beberapa kekurangan seperti ruas jalan yang menjadi prioritas perbaikan pada urutan 3-10 memiliki kondisi jalan yang baik. Hal tersebut dikarenakan ruas jalan pada peringkat 3-10 memiliki bobot yang tinggi pada fungsi dan kelas jalan.

Dari hasil dan kesimpulan penelitian ini, terdapat beberapa point yang dapat dijadikan saran untuk penelitian berikutnya yang serupa. Point tersebut adalah penggunaan metode lain yang dapat meminimalisir ketidaktepatan penentuan prioritas, seperti pada kasus kondisi jalan baik namun masuk dalam urutan ke 3 untuk diperbaiki dan untuk algoritma dapat dicoba menggunakan Fuzzy AHP.

\section{Referensi}

Apriani, W., \& Santony, J. (2019). Prioritas Pengaspalan Jalan Menggunakan Metode Analytical Hierarchy Process (Studi Kasus Di Dinas PU Deli Serdang). Jurnal Ilmiah Komputasi, 18(1). https://doi.org/10.32409/jikstik.18.1.2561

Mubarok, A., \& Rosmiati, A. (2016). Sistem penunjang keputusan prioritas perbaikan jalan menggunakan metode analytical hierarchy process. Informatika, 3(September), 200-207. http://ejournal.bsi.ac.id/ejurnal/index.php/j i/article/view/818

Nababan, D. (2014). Prioritas Perbaikan Jalan Di Kota Medan Dengan Menggunakan Metode Analitycal Hierarchy Process ( Ahp ). 2, 14-19.

Panjaitan, T. M., Imrona, D. M., Aditsania, A., \& $\mathrm{Si}$, M. (2018). Penentuan Prioritas Perbaikan Jalan dengan Menggunakan Metode AHP di Wilayah Kabupaten Serdang Bedagai Sumatera Utara Priority Road Repair by Using AHP Method in the District of Serdang Bedagai Sumatera Utara Alternatif m. 5(2), 3804-3811.

Pratama, R. R., Imrona, M., \& Aditsania, A. (2018). Penentuan Prioritas Perbaikan Jalan dengan Menggunakan Metode Analytic Hierarchy Process (AHP) dan COPRAS-G di Kota Tangerang. In Indonesian Journal on Computing (IndoJC) (Vol. 3, Issue 1, p. 103). https://doi.org/10.21108/indojc.2018.3.1.2 19

Rahman, F., Furqon, M. T., \& Santoso, N. (2018). Sistem Pendukung Keputusan 
Penentuan Prioritas Perbaikan Jalan Menggunakan Metode AHP-TOPSIS (Studi Kasus: Dinas Pekerjaan Umum dan Penataan Ruang Kabupaten Ponorogo). Jurnal Pengembangan Teknologi Informasi Dan IImu Komputer, 2(11), 4365-4370.

Setya Krismawati, N. E. (2014). Analisis Prioritas Penanganan Ruas Jalan Strategis Untuk Pengembangan Wilayah di Kabupaten Demak. Jurnal Wilayah Dan Lingkungan, 2(2), https://doi.org/10.14710/jwl.2.2.99-112

Setiawan, A. (2019). Penentuan Skala Prioritas Penanganan Ruas Jalan Provinsi di
Kabupaten Purwakarta. Jurnal Soshum Insentif, https://doi.org/10.36787/jsi.v2i1.54

Brodjonegoro, P. (1991). Petunjuk Mengenai Teori dan Aplikasi dari Model Analytical Hierarchy Process. Jakarta,Indonesia: Sapta Utama.

Saaty, T. L. (1990). The Analytic Hierarchy Process: Planning, Priority Setting, Resource Allocation.

Saaty, T. L. (1993). Pengambilan Keputusan Bagi Para Pemimpin. Jakarta, Indonesia. 